\title{
The Effectiveness of Using Movies in the EFL Classroom - A Study Conducted at South East European University
}

\author{
Merita Ismaili ,MA, \\ South East European University (SEEU) \\ E-mail: merita.ismaili@seeu.edu.mk
}

\section{Doi:10.5901/ajis.2012.v2n4p121}

\begin{abstract}
:
Being exposed to different media and technology resources, from audio to printed material students lack the motivation for learning in conventional way. This is the main reason why English language teachers always keep searching for more motivating teaching sources. Course books and CD's offered in English classes turn out to be artificial and not very engaging for students. One way of bringing variety into the classroom is the use of movies in EFL teaching. . This paper analyzes the effects of using movies in the EFL classroom. It reveals its effects on developing students listening and communication skill. The study was conducted on a sample of two groups: an experimental and a control group taught conventionally. The study was carried out at the South East European University in the academic year 2011/2012. The participants in this study were pre-intermediate and intermediate level of students, aged 18-25. The results of the study have shown that significant differences between experimental and control group of students on integrated skills, using video incorporated in the teaching material. The study concluded that movies attract students' attention, present language in a more natural way that found in course-books. What is more important movies offer a visual context aids which help students understanding and improve their learning skills.
\end{abstract}

Key words: media, movies, teaching English, communication skill, comprehension.

\section{Introduction}

Teaching English nowadays has become more challenging than ever. In order to help the learners' mastery (increase the proficiency) of language skills, language teachers have to provide quality teaching materials that will be engaging, interesting, up-to-date while simultaneously being a tool that will ensure that the students learn.

Many scholars have revealed that movies used in EFL classroom can become an important part of the curriculum. This is based on the fact that movies provide exposures to "real language," used in authentic settings and in the cultural context which the foreign language is spoken. They also have found that movies catch the learners' interest and it can positively affect their motivation to learn (Kusumarasdyati, 2004; Luo, 2004).

As an English teacher at South East European University (SEEU), I've had difficulties in engaging students in the reading activities. The graded readers that students use in our university are often intimidating to students because, when reading novels, students often come to know characters best not through what they say, but through what they are thinking or what is said about them in the narration. A storyteller pictures the meaning of what is read through his or her point of view. As nowadays, students don't read much, many characters are unknown for them, especially those in classical novels. This usually frustrates them therefore reading classes are very boring to them.

For the majority of students, the settings and historical context presented in graded readers are foreign to them. Therefore, they do not feel motivated and show no interest in reading. Contemporary scholars on media literacy believe that the same habits that a good reader brings to a written text are those that bring students to a visual text (Golden,2001). According to those scholars students predict, make connections, ask 
questions, and interpret when faced with written or visual texts. In both situations, meaning is made through the details of character, theme, plot, mood, conflict, and symbolism. Thus, teachers should use this opportunity in order to guide students to be active interpreters.

Movies are an enjoyable source of entertainment and language acquisition. For this reason, many scholars and EFL practitioners prefer to watch the movie adaptations of famous and current novels as a supplementary source to the reading. Practice has shown that reading an entire book can be tiresome and boring while an audio-visual experience can be more entertaining and engaging to students.

The objectives of this study are:

- To elaborate and analyze the effectiveness of using movies on development of the students language competence and performance in academic settings.

- To examine if using movies can be engaging and helpful for students get more engaged with the reading activities.

- To examine if watching movies may serve as a bridge between learning skills and language objectives (output)

\section{Literature Review}

Although there are many studies conducted regarding using the movie in EFL classes, very few studies were done on the use of movies for enhancing reading comprehension; with the exception of one study (Weyers, 1999).

On the other hand, there are numerous studies on the use of videos in developing particular language skills, especially listening comprehension, (Wetzel,Radtke \& Stern, 1994; Ginther, 2002; Gruba, 2006; Opat, 2008; Suvorov, 2008; Chung, 1994; Ockey, 2007).

Herron and Seay (1991) had conducted research on using video in listening comprehension for EFL students. He used intermediate level of students and has divided them into two groups, experimental and controlled group. The experimental group has substituted the regular classes with listening to the authentic radio tapes. The controlled group followed the regular class activities without and exposure to the radio tapes. The study has provided evidence that the experimental group performed significantly better on the final tests of listening comprehension with both the video and the audio than did the control group in which no strategy training occurred.

Herron, et al. (1995) has come to the conclusion that ...

"Video is lauded for contextualizing language (i.e., linking language form to meaning) and depicting the foreign culture more effectively than other instructional materials. Videotapes permit students to hear native speakers interacting in everyday conversational situations and to practice important linguistic structures. Unlike audiocassettes, video's visual dimension is thought to reduce ambiguities present in native speaker voices and to motivate students to want to learn the foreign language" (Herron, et al., 1995, p. 775).

In addition, videos provide interesting and motivating clues to accompany audio or written inputs, therefore it supports comprehension and production of foreign language input/output (Hanley, et al., 1995; Herron, et al., 1995; Wen, 1989; Weyers, 1999). Furthermore, movies provide language learners with the opportunity to view the social dynamics of communication as native speakers interact in authentic settings (Herron, et al., 1995; Lonergan, 1992; Kerridge, 1982; Singer \& Singer, 1998; Swaffar \& Vlatten, 1997; Wellman, Keniston \& Westby, 1978; Coniam, 2001).

Other scholars have concluded that movie fragments help enhance memory and recovery of information in reading and listening (Pezdek, Lehrer, \& Simon, 1984). Using the same pattern, film may help develop writing skills through providing interesting and motivating clues to accompany audio or written inputs, in that way it assists comprehension and production of foreign language input/output (Hanley, et al., 1995).

Herron and Hanley (1992) concluded that using movies in EFL classroom offers background information that activates prior knowledge, which is essential in stimulating the four skills activities in the classroom. 
Joseph R. Weyers(1999) carried out a study with an authentic soap opera to measure whether it can increase students listening comprehension and enhance their oral production. For his research, he used a control group and experimental group. The experiment was conducted in two second-semester Spanish classes for 8 weeks at the University of New Mexico. All students took pre- and post-treatment tests. Both groups followed the established curriculum for second-semester Spanish. However, the experimental group was supplemented by watching two episodes of a Spanish soap opera per week. Before viewing each episode, the teacher gave the participants a short summery in English of the telenovela. At the end of the study, the results of the experiment suggested that telenovelas are a valuable source in increasing the students' listening comprehension skills.

Luo, J.J (2004) in his study examined the influence of DVD movies on students' listening comprehension. Nine films were incorporated into the class curriculum over the entire school year. The DVDs were the main materials of the course, supported by specially designed additional activities. Instructional activities included story-telling, picture description and open-ended questions for group discussion on topics retrieved from the movies. The researcher incorporated caption-on and caption-off activities in order to practice student's listening skills. The final results of the statistical analyses indicated that student's listening skill "did improve" through the instruction of using DVD movies in a motivating learning environment with "lower level of anxiety" after a whole school year (Luo, 2004).

Movies and W-R-W-R (Hibbing \& Rankin-Erickson, 2003) (the watch-write-watch-write method)

Movies provide a wonderful opportunity for students to gain background understanding to combine with their own understanding about a story or concept. When reading a text, movie features can help students connect to new information they may have not had background in and adapt their new thoughts, images, and feelings to the text at hand (Gambrell \& Jawits, 1993). Hibbing and Rankin-Erickson suggest using a WatchRead-Watch-Read (W-RW- R) method in which students will build some background of the text, make predictions, watch part of the movie, read more of the text, confirm understandings, make more predictions, watch more of the movie, and continue reading the text (Rankin-Erickson ,2003).

The main component of using the movies in the class is actually enabling the reader to picture or to visualize the events, characters, narration, story and words in the context. Draper (2012) has characterized visualization as a very important prerequisite for a good reader. She has studied and concluded the following key points regarding the reading process and visualization:

- Proficient readers spontaneously and purposefully create mental images while and after they read.

- The images emerge from all five senses, as well as emotions, and are anchored in readers' background knowledge.

- $\quad$ Proficient readers use images to immerse themselves in rich detail as they read. The detail gives depth and dimension to the reading, engaging the reader more deeply, making the text more memorable.

- Proficient readers use images to draw conclusions, to create distinct and unique interpretations of the text, to recall details significant to the text, and to recall a text after it has been read. Images from readers' personal experience frequently become part of their comprehension.

- Proficient readers adapt their images as they continue to read. Images are revised to incorporate new information revealed through the text and new interpretations as they are developed by the reader.

- Proficient readers understand and articulate how creating images enhances their comprehension. Draper,(2012)

Scholars have defined visualization as the ability to build mental pictures or images while reading. It is evident that our own visualizations, when reading the script, would greatly depend upon our prior knowledge and engagement with the topic (Keene \& Zimmerman, 1997)

This is a great support on why should English teachers be more innovative, motivating and support the use of movies in English classes. 
Helping our students gain visualization skills is an important way to foster greater comprehension when reading. It allows students the ability to become more engaged in their reading and use their images to draw conclusions, create interpretations of the text, and recall details and elements from the text (Keene \& Simmerman, 1997).

\section{Participants}

The participants in this study were SEEU undergraduate students, between the ages of 18-25. The total sample of participants consisted of 60 students, male and female, all in a multicultural classroom setting. Their level of proficiency is pre-intermediate and intermediate. The study took place over three month period of time. The study was conducted on a sample of two groups: an experimental group exposed to video which accompanied the reading section activity and a control group taught conventionally. The discussions of the findings are presented according to the research questions of the study. The study was carried out at the South East European University (SEEU) in the academic year 2012. In this study, in order to get teacher's perception on using movies in ELT classroom, six teachers who were willing to participate in this study (and have already implemented the movies in their classes) were sent a questionnaire.

\section{Method}

Two types of data collection were used:

1. Questionnaire for students

2. The quiz given at the end of the reading section

1. Data are collected through students' and teachers' questionnaire which investigates their attitudes towards movie-based teaching and learning. The questionnaires are designed in the form of a 5point Likert scale ranging from "Strongly Disagree" to "Strongly Agree." The questionnaires were distributed to six LC English teachers and to the 60 students.

2. The quiz was given to both controlled and experimental group at the end of the reading section.

This study is primarily concerned in contributing to the quality of the process of teaching and learning, through the use of media, particularly using movies in ELT classroom. During the in-class reading, students seem to be very bored. They were asked to read the whole book, and complete the quiz at the end. The reading activity was also followed by pre and during activities, but students usually fail to complete them. This was mostly because classes are not heterogeneous regarding their proficiency (although they all belong to a certain level).Their learning styles, instinct motivation were just some of the key components that influenced in their bad scores on the reading quiz. On the other hand, neither the speaking activities, like book debates, were not very sufficient. Students hesitate to participate in speaking activities and all this resulted to a very dull English class. This fact, was not frustrating only for the students, but for the teachers as well.

Having read different articles and studies on the successfully movie-based classes I decided to conduct a study on this field and observe its results.

For the purposes of this study the controlled and experimental groups were used. A class of 28 students was subject to the experiment and the remaining thirty-two students served as a control group. The experimental group watched a novel-based movie in English before their reading class, where they are going to read the same novel (after they had watched the movie) on the graded reading Books (Oxford University Press). The control group students were given the same readers, with the same question activities but without the movie accompanying the books.

The study attempts to answer these research questions:

- What are the teachers' attitudes towards the using movies on development of the students' language competence and performance in academic settings?

- What are students' perceptions towards using movies in EFL classroom?

- Does watching the movies serve as a bridge between reading skills and listening skills? 


\section{Procedures}

For purposes of this study, two texts "The Frankenstein" and "The Gulliver's travels" were chosen, and used as in-class reading for both groups (controlled and experimental). Additionally, the experimental group watched films of these two novels. However, classroom procedures and teaching methods were different for each group. These two movies were chosen because they are required on the syllabus but also because students found these readers very difficult to analyze and understand.

The controlled group used the usual procedure and activities for the in-class reading. In both cases, at the beginning of the class, students were given a short list of vocabulary words and phrases used in the book in order to prepare them for better understanding of the story.

The controlled group reading class began with a cover picture and the book title for discussion, then getting started by activating their previous knowledge, and getting ready to read; at this stage students are given pre-reading questions and True/False questions as a brainstorming activity. At the end the students are given post-reading questions in order to check comprehension.

For the Experimental Group, the movie trailer introduced the core theme. Students were also given True/False questions as a brainstorming activity. All through movie class, students viewed segments of ten-tofifteen-minute video material. As the students watched the tape, the teacher stopped occasionally to check comprehension. During this time students had "while-watching" questions, which purpose was to check comprehension but also force students to better concentrate on the movie.

After watching the movies, the experimental group received a questionnaire whose aim was to illicit students' feedback regarding using the movie in the classroom and to investigate the relationship between movie-viewing and student's performance.

After movie viewing, students (of the both groups) were given quiz with vocabulary, writing and speaking activities. The vocabulary exercises consisted of comprehension questions, True /False questions. For the writing activity, students had to write a brief summary of the story. And finally, as a follow up activity, both groups' students were given an oral assignment 2-3 min for each student to describe best/worst character of the story.

Although presenting full-length movies in a classroom is time consuming, after some practicing it does not necessarily become a significant obstacle. In the SEEU where I have implemented this teaching technique, one session of lesson lasts for 100 minutes. This facilitates showing one entire movie (approximately 90-115 minutes long). On the other hand, doing the relevant exercises cannot be completed in a single session, but this can be easily overcome by splitting the activities into two sessions.

\section{Interpretation of Findings / Results}

The findings reviewed in this study showed significant differences between experimental and control group of students on integrated skills using video incorporated in the teaching material. We might conclude that motivational factors associated with movie-based teaching helped to increase the efficiency of the teaching and learning process.

1. What are the teachers' attitudes towards the using movies on development of the students' language competence and performance in academic settings?

The general impression of the teachers is that movies have a positive effect on students' language learning process. They believe that using movies combined with the readers helped students to become active participants in the classroom activities. Teachers claimed that movies can enhance the interaction among students in class; they improve learners' communicative competence and provide students with more opportunities to use English. They also claim that they faced difficulties while selecting suitable movies for different proficiency levels and that watching a movie might be very time consuming. Almost all teachers 
received positive feedback from students when they involved movies along with the reading activities and as a result students were participating in the classroom debates and vocabulary activities as well as written assignments related to the movie review. The following statements are taken from the teachers' questionnaire results and may be summarized into several points:

- The interviewed teachers did not receive any special training regarding the usage of movies in classroom. However four of them have had a presentation on using smart board and its audio visual effects.

- All teachers strongly agreed that movies should be integrated in syllabus design and used in classroom.

- Video clips (YouTube, etc) were mostly used by teachers during their classes; as they were more suitable to fit to the class time.

- Only one, out of six teachers used novel-based move, whereas others claimed to use movies or clips related to student's learning area (ex ESP).

- Regarding the frequency of the movies used in the classroom, most of them use once-twice a semester. Only two of them used every few months.

- One of the main reasons why teachers don't use movies more often appeared to be the time constrain. Related to student's learning area ( ex ESP).Watching a movie takes too much time, and sometimes the class has to be split into more sections in order students to achieve better results and all follow up activities to be implemented.

- Most of the teachers think it's very hard to find suitable movies for ESL students. Although the internet offers downloadable versions of the movies needed, it's hard to find movies with less than 100 min viewing.

- On the other hand, none of the teachers thinks that it is difficult to incorporate movies in to the syllabuses. They share the opinion that this can easily be done, but it needs time to prepare the lesson flow and put all the components needed for watching and analyzing the movie in ELT classroom.

- While, one of the teachers answered that that movies are suitable for the classroom only to fill the time, others claimed the opposed and strongly disagreed with this statement.

- All teachers confirmed that movies are a useful resource for oral English language teaching, and they emphasized that movies are a useful resource for teaching English vocabulary. This is supported by the positive feedback they get from students when using movies in teaching.

- Teachers have been using movies in English class supporting the oral language skills like: class debates on the movie and group discussions.

- Teachers have been using movies in English class for the following assignments: movie review, fill in the blank activities (ex. from the movie scene) or for writing essays.

From the above mentioned statements, one can conclude that the Language Center teachers do actively use the movies in their teaching for different purposes, though the movies are not part of the syllabuses.

\section{What are students' perceptions towards using movies in EFL classroom?}

Using movies in the classroom was new and very pleasant experience for the students. They claim that they enjoyed the assigned activities in the classroom. Students were more motivated to see and hear real-life situations than to follow the activities in the graded book. Their impression is that movies also provide a relaxed atmosphere for students. Students claimed that using movie is a good way to improve English vocabulary and gives them more chances to practice English. Most of students said that they have learned new words (approximately 3-5) mainly because those words that have been repeated many times throughout the film. According to them, key word preview given at the beginning of the class facilitates learning and it 
helped them to understand clearly the content of the movie. From the students questionnaire we might conclude that:

- Students preferred genres are comedy and action movies and they do believe that English movies have beneficial effect on learning English.

- Students' answers show that they are interested in learning English if the teacher uses English films as teaching materials.

- They were neutral regarding the questions do they think that their movie preferences will affect their learning and do they think English captions are good in learning English. This may be very reasonable answers having in mind that they didn't have too much exposure to the movie-based teaching in order to be able to measure their achievements and be able to give more concrete answers.

- Regarding the keyword preview, which method was also applied in this study, students agree that it helped them understand the story line of a movie and that the keyword preview before movie viewing motivated them to learn English.

- Students agreed that movies are useful in learning English and that they have learned some English by watching the movie. They mostly learned words that were repeated many times.

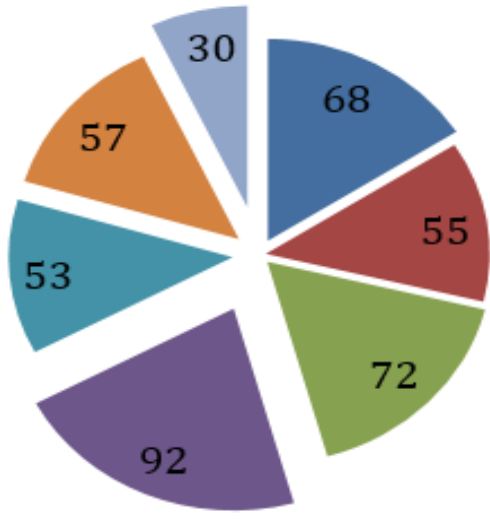

\author{
- you think watching English \\ movies has a beneficial effect on \\ learning English? \\ - Do you think your movie \\ preferences will affect your \\ learning? \\ - Do you think English subtitle are \\ good in learning English? \\ - I am interested in learning \\ English if the teacher uses English \\ films as teaching materials. \\ - Do you think this film is useful in \\ learning English?
}

\footnotetext{
Do you agree you have learned some English by watching the film?

Do you think the dialogs in the movie can be used in daily life?
}

\title{
Does watching the movies serve as a bridge between learning skills?
}

The questionnaire's results show that students can learn more effectively when their attention is focused on the task; therefore they are focused more on the language they use than on the grammatical forms. The classroom atmosphere is comfortable, cooperative and there is a lot of interaction among students. As a result students score better results at all skills. In addition, different types of tasks stimulated different patterns of 
interaction. As in reading, good listeners make good use of chunks to understand what they hear (Hawkins et al., 1991).

From the students' responses to the questions concerning the development of speaking skills in the questionnaires revealed that students have positive approach toward this method. Students responses indicated that the advantages of using movies to teach listening and speaking increased learning interests and motivation. Students claimed that it provides the chance for learning real-life conversation. Movies helped improve listening comprehension and speaking ability.

Listening and reading are active process of trying to understand (comprehend) the meaning of a word, a phrase or a sentence. Students of the experimental group scored much better results from the controlled group. After watching the movie, they were more motivated to read the simplified reader. They also were keener to participate in group discussions. They were able to discuss and analyze the characters and had a clearer picture of the events.

While watching the movie and completing the vocabulary activities, students acquire and use new words. Learning new vocabulary helps students become more fluent because the more words they know, the easier it is to express themselves. All these processes encourage students to develop critical thinking skills. In ELT classes, words and expressions are studied in isolation from their meaningful context. By using the movies, teachers attempt to focus instructions on lexical chunks. Movies represent a unique environment in this respect. At this point, students can access, view, and repeat texts that are richly contextualized by good features of accompanying visual and textual information. Another important benefit of movies is that students are able to recognize core vocabulary and the rules and patterns of words used to communicate.

\section{Advantages and disadvantages of using the movies as a supplementary resource}

One of the advantages of using the movie is that visual images stimulate student's perceptions directly, while written words can do this indirectly. Movies are more sensory experience than reading -- besides verbal language, there is also color, movement, and sound.

The movie-based experimental class was livelier and the students were more interested in following the lesson carefully, contrary to the other class were reading was presented through graded readers only. Movieviewing experiences further created more student-teacher and student-student discussions. Movies draw students' attention and captured their interest. The benefit of using the movies in teaching and learning is unquestionable. Among its positive sides there are some disadvantages as well.

Among the most common disadvantages cited by the participating teachers was that using movies in the classroom meant lost class time and the difficulty of showing movies in class periods.

As the main disadvantage in watching the movie is that a movie must generally reduce events into two hours or so while there is no time constraint on a novel. While the meaning of a novel is controlled by the writer, the meaning students get from a film is the result of a mutual effort by a large number of people. Another disadvantage is that movies do not allow interacting with the plot or characters by imagining them in our minds. For some teachers, this is often the most frustrating aspect of turning a novel into a movie. Some students might resist viewing the movie without or with English subtitles. These films take more effort to follow because of the need to read the subtitles and watch the scenes.

\section{Pedagogical Implications and Suggestions for Further Research}

This study was an investigation on the correlation between the viewing the movies and effective learning in EFL classrooms. Although the study revealed that movies could facilitate the learning is not necessarily a must. It greatly depends on how pedagogically appropriate movies are used and how effective it is used in teaching. Movies and their special features such as subtitles were of a great help to develop an effective learning environment. 
Poor readers tend to have little background knowledge about the text, which causes them to have difficulty comprehending what they are reading (Anderson \& Pearson, 1984). Since films supply additional background information, they can activate schema to aid reading comprehension (Mei-Ling Chen , 2012).

Based on the findings of the study, three pedagogical implications were emphasized.

First, teachers can employ movie-based instruction to improve students' listening and speaking skills. Second, teachers can increase students' interests and learning motivation by incorporating movies in the reading activities. Last but not least, activities derived from the films, such as dictation, group discussion, and oral presentation, can also enhance students' listening and speaking skills.

\section{Limitation}

Time for implementation of this experiment was too short; maybe implementing this method over more periods of time may yield different findings. The study was limited to a relatively low number of students. It should also be assess in other language levels as EAP, ESP etc.

\section{Reference}

Anderson, R. C., \& Pearson, P. D. (1984). A schema-theoretical view of basic processes in reading comprehension. In P. D. Pearson (Ed.), Handbook of reading research (pp. 255-291). New York: Longman.

Chen, M. L. (2012). Effects of integrating children's literature and DVD films into a college EFL class. English Teaching: Practice and Critique, 11(4).

Draper.D (2010-2012) Comprehension Strategies.Visualising \&Visual Literacy. DECS Curriculum Consultant, Northern Adelaide

Gambrell, L.B., \& Jawitz, P.B. (1993). Mental imagery, text illustrations, and children's story comprehension and recall. Reading Research Quarterly, 28, 264-276.

Ginther,( 2002) Context and content visuals and performance on listening comprehension stimuli. Language testing, 19 (2), 113-167.

Golden, John. Reading in the Dark: Using film as a tool in the English classroom. Urbana, IL: National Council of Teachers of English,2001

Gruba,P( 2006) Playing the videotext: A media literacy perspective on video-mediated L2 listening. Language learning and technology,10 (2),77-92

H. C. Liou, J. E. Katchen, and H. Wang (2003), Lingua Tsing Hua (pp. 221-236) Taipei: Crane,.

Hsieh, H. L., WU, J. Y., Lai, P., Chang, S. K., Chen, T. Y., \& Kao, W. J. (2010). The effect of movie viewing on learning English as a foreign language. Retrieved November, 12, 2010.

Hibbing, A. N., \& Rankin-Erickson, J. L. (2003). A picture is worth a thousand words: Using visual images to improve comprehension for middle school struggling readers. The Reading Teacher, 56(8), 758-771

Luo, J. J. (2004). Using DVD films to enhance college freshmen's English listening comprehension and motivation. Unpublished Master thesis, National Tsing Hua University, Hsinchu. Taiwan, R.O.C.

Suvorov,R.(2008).Context visuals in L2 listening text. The effectiveness of photographs and videos vs. audio-only format. Master thesis, lowa State University, lowa

Weyers, J. R. (1999). The effect of authentic video on communicative competence. Modern Language Journal, 83(3), 339349.

Keene, E., \& Zimmerman, S. (1997). Mosaic of thought: Teaching comprehension in a reader's workshop. Portsmouth, NH: Heinemann.

Kusumarasdyati,(2004) . Listening, Viewing and Imagination: Movies in EFL Classes. $2^{\text {nd }}$ International Conference on Imagination and Education Vancouver, Canada, July 14 - 17, 2004.

Wetzel,Radtke \& Stern, (1994). Instructional effectiveness of video media.Using DVD Films to Enhance College Freshmen's English Listening Comprehension and Motivation, MA thesis, National Tsing Hua University, Taiwan.

Lin, L. Y. (2002). The effects of feature films upon learners' motivation, listening fostering whole language learning (Felhman, 1996; Weyers, 1999). 


\section{Appendixes}

The Questionnaire for English Teachers (adapted from Hsieh, H. L., WU, J. Y., Lai, P., Chang, S. K., Chen, T. Y., \& Kao, W. J. (2010).

The survey intends to collect data on using movies as teaching material in ESL classroom. The survey refers to films such as DVD movies or clips of movies available on the Internet. Choose what best suited option / options, and/or justify your answer on request as accurately as possible.

\section{Have you received training at some point in some of the following?}

$\square$ Media Education $\quad$ 口Films in teaching

$\square$ Other alternative modes of instruction (eg, drama education, software using, etc.),

口None

\section{Movies should be used in the EFL classroom?}

Strongly Agree $\square \quad$ Agree $\square \quad$ Neutral $\square \quad$ Disagree $\square \quad$ Strongly Disagree $\square$

3. I have used___ as teaching material in English class:

$\square$ Whole movies (eg DVD)

$\square$ Clips from films (for example, trailers)

$\square$ Video clips, (eg, YouTube)

口 I have not used at all film-related audio-visual material.

$\square$ other

4. What types of movies have you used as teaching material in English class?

$\square$ Novel based $\quad \square$ Comedy $\quad \square$ Related to student's learning area (ex ESP)

口other

5.How often have you used the movies / video clips in your classroom?
$\square$ Once a semester
$\square$ twice a semester
$\square$ Never
$\square$ once a month
$\square$ Every few months
$\square$ Other

6. I think that using movies in English classes takes too much time!
$\square$ Strongly Agree
$\square$ Agree $\quad$ Neutral $\square$ Disagree
$\square$ Strongly Disagree

7. I think it's very hard to find suitable movies for ESL students.

$\square$ Strongly Agree $\quad \square$ Agree $\quad \square$ Neutral $\square$ Disagree $\quad \square$ Strongly Disagree

8. It is very difficult to incorporate movies into curriculum.

$\square$ Strongly Agree $\quad \square$ Agree $\square$ Neutral $\square$ Disagree $\square$ Strongly Disagree

9. I think that movies are suitable for the classroom only to fill the time.

$\square$ Strongly Agree $\quad \square$ Agree $\quad \square$ Neutral $\square$ Disagree $\quad \square$ Strongly Disagree

10. I think movies are a useful resource for oral English language teaching. 
$\square$ Strongly Agree

$\square$ Agree $\quad \square$ Neutral $\quad \square$ Disagree $\quad \square$ Strongly Disagree

11. The feedback I received from students when using movies in teaching has been positive.

$\square$ Strongly Agree $\quad \square$ Agree $\quad \square$ Neutral $\quad \square$ Disagree $\quad \square$ Strongly Disagree

12. I think movies are a useful resource for teaching English vocabulary.

$\square$ Strongly Agree $\quad \square$ Agree $\square \quad \square$ Neutral $\quad \square$ Disagree $\quad \square$ Strongly Disagree

13. I've been using movies in English class oral language skills teaching assignments in the following:

$\square$ General debate on the movie theme

$\square$ Group Discussion/debate

$\square$ Drama task (for example, students play the movie scene again)

$\square$ Other, what?

\section{I've been using movies in English class to write teaching assignments in the following:}

$\square$ Fill in the Blank eg, from a movie scene

$\square$ Essay

$\square$ To write a movie review

$\square$ Other, what?

The Questionnaire for Students (adapted from Hsieh, H. L., WU, J. Y., Lai, P., Chang, S. K., Chen, T. Y., \& Kao, W. J. (2010).

Q1. What kinds of English movies do you like? (You can choose more than one.)

$\square$ Thriller $\square$ Comedy $\square$ War movies $\square$ Documentary

$\square$ Romance $\square$ Suspensor $\square$ Science Fiction $\square$ Action movie

$\square$ Animated movie

Q2. Do you think watching English movies has a beneficial effect on learning English?

$\square$ Strongly Agree $\quad \square$ Agree $\quad \square$ Neutral $\quad \square$ Disagree $\square$ Strongly Disagree

Q3. Do you think your movie preferences will affect your learning?

Q7. Do you think English captions are good in learning English?

Q9. I am interested in learning English if the teacher uses English films as teaching materials.

Q10. Does keyword preview help understand the story line of a movie?

Q11. Do you agree keyword preview before movie viewing motivate you to learn English?

Q13. Do you think this film is useful in learning English?

Q14. Do you agree you have learned some English by watching the film?

Q15. How many English sentences have you learned from the movie?

1-3 sentences 3-5 sentences 5-7 sentences More than $10 \quad$ No reply

Q16. Can you write down any words and sentences you have learned from the movie? 
E-ISSN 2281-4612

ISSN 2281-3993
Academic Journal of Interdisciplinary Studies Published by MCSER-CEMAS-Sapienza University of Rome
Vol 2 No 4

May 2013

Been repeated many times

Have learned before

$$
\text { No reply }
$$

Too funny

Abusive language

Q18. Do you think the dialogs in the movie can be used in daily life?

Q19. Do you think key word previewing helps understand the movie and has positive effect on learning? 